\title{
Outsourcing and Low-Skilled Workers in the UK
}

Bob Anderton and Paul Brenton

CSGR Working Paper No. 12/98

July 1998
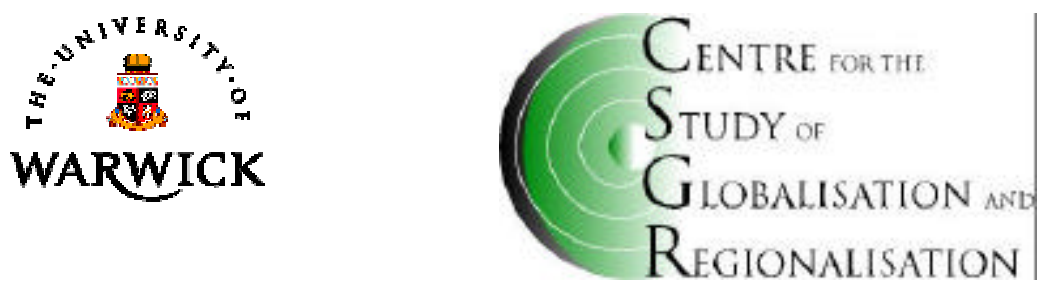


\title{
Outsourcing and Low-Skilled Workers in the UK
}

\section{Bob Anderton and Paul Brenton ${ }^{1}$}

National Institute of Economic and Social Research, London, UK, and Centre for European Policy Studies, Brussels, Belgium

CSGR Working Paper No. 12/98

July 1998

\begin{abstract}
:
This paper investigates the impact of 'outsourcing' on the relative wages and employment of the low-skilled in the UK. In contrast to previous studies which proxy outsourcing by imports from all countries, we examine whether the source of imports is important. We disaggregate UK imports according to individual supplier countries and construct import penetration terms for different groups of countries - ie, distinguishing between imports from industrialized countries and imports from low-wage countries - for each 4-digit industry within the broader categories of textiles and non-electrical machinery. Our econometric results show that imports from low-wage countries have made a significant contribution to the decline in the relative wages and employment of the less-skilled in the UK, with no discernible effect resulting from imports originating from industrialised countries. The estimates suggest that rising imports from low-wage countries may account for about 40 per cent of the rise in the wage bill share of skilled workers, and approximately one-third of the increase in their employment share, in the UK textiles sector during the period 1970-1983. We also offer some limited evidence that the degree of outsourcing may differ across industries and that large currency appreciations may have a disproportionately large impact on the economic fortunes of the less-skilled, partly by creating an increased 'threat' of outsourcing.
\end{abstract}

Keywords: Outsourcing, manual and non-manual workers, inequality. JEL Classification: J31

Address for correspondence:

Bob Anderton,

NIESR,

2 Dean Trench Street,

Smith Square,

London, SW1P 3HE.

Tel. No: 0171222 7665;

Fax. No: 0171222 1435;

Email: r.anderton@ niesr.ac.uk

\footnotetext{
${ }^{1}$ Acknowledgments: We are extremely grateful to Mary O'Mahony for supplying us with Census of Production and capital stock data. We are also in debt to Jonathan Haskel and two anonymous referees whose comments on an earlier draft substantially improved the paper, but any errors remain the responsibility of the authors. This research forms part of the Globalisation and Social Exclusion project funded by the European Community under the Targeted Socio-Economic Research (TSER) Programme.
} 


\section{Non-Technical Summary:}

In the UK, the relative wages and employment of the low-skilled fell dramatically during the 1980s. During that decade the real earnings of the top tenth of male earners in the UK rose at a rate five times faster than that of the earnings of the bottom tenth of male earners. The unemployment rate of less-skilled males in the UK rose from $6.4 \%$ in the mid-1970s to $18.2 \%$ by the mid-1980s, whereas over the same period the unemployment rate of skilled males only rose from $2.0 \%$ to $4.7 \%$. Two main explanations are frequently offered for the apparent shift in demand away from low-skilled workers in the UK and other industrial countries. First, that skillbiased labour-saving technical progress has reduced the relative demand for unskilled workers; second, that increased international trade with nations with an abundant supply of low-skill and low-wage labour has decreased the demand for low-skilled workers in the advanced industrialised countries.

One explanation of how trade with low-wage countries may push down the relative wages and employment of unskilled workers within industries is provided by the notion of 'outsourcing'. Outsourcing occurs where firms take advantage of both the low-wage costs of relatively labour abundant countries and modern production techniques - whereby the process of manufacturing a product can be broken-down into a number of discrete activities - by moving the low-skillintensive parts of production abroad, but continue to carry out the high-skill-intensive activities themselves. Once the low-skill activities have been performed the goods are then imported back from the low-wage countries and either used as intermediate inputs or sold as finished goods. Hence, trade with the low-wage countries via this route will shift employment away from lessskilled towards skilled workers in countries such as the UK, and put downward pressure on the relative wages and employment of low-skilled workers within industries. 
In this paper, we empirically assess whether outsourcing has influenced inequality in the UK by disaggregating UK imports according to individual supplier countries and constructing an import share term for different groups of countries - ie, industrialised and low-wage countries - for each 4-digit industry within the broader categories of textiles and non-electrical machinery. Thus, we explicitly identify imports solely from low-wage countries and use this as a variable for explaining changes in the relative wages and employment of the low-skilled in the UK, and thereby more accurately proxy outsourcing to low-wage countries. In common with most studies on this issue we define non-manual workers as skilled and manual workers as less-skilled.

We also investigate two other closely related hypotheses. First, given that one might expect lowskill-intensive industries (such as textiles) to be more prone to outsourcing than high-skillintensive sectors, we investigate whether the degree of outsourcing differs across industries. Second, we also consider whether the large appreciation of sterling in the early 1980s had a disproportionate impact on outsourcing due to factors such as switching costs - ie, if there are costs involved in moving from domestic sources of supply to a foreign source then a large appreciation of the currency of the importing country may result in a price differential vis-a-vis low-wage country suppliers which is large enough to compensate for the switching costs - and whether this mechanism has any impact on the economic fortunes of the less-skilled by increasing the 'threat' of outsourcing.

Our results show that UK imports from low-wage countries have a statistically significant influence on the share of the wage income and employment of the less-skilled, but that imports from the industrialised countries have no effect on the relative economic fortunes of the lessskilled. Both sets of results are therefore consistent with our expectations regarding the impact of outsourcing. We also find that the price of imports from low-wage countries relative to the price of UK products explains some of the rise in UK inequality. It may be the case that this relative 
price term captures the 'threat' of increased competition from low-wage countries (and the associated 'threat' of increased opportunities for reducing labour costs via outsourcing) arising from the large appreciation of sterling. Therefore, as an alternative to reducing labour costs by outsourcing, this increased 'threat' may have encouraged other firms to implement measures which restrain the wages - and perhaps terminate the employment - of less-skilled workers in order to remain competitive against low-wage countries. At the same time, the 'threat' of outsourcing may have made it considerably easier for firms to obtain the agreement of their workforce for the implementation of such measures.

In summary, this paper provides some evidence that outsourcing may have damaged the economic fortunes of the less-skilled in the UK. For the period 1970-83 (Charts 1 and 2 in the paper show that most of the change in the relative wages and employment of the less-skilled in the UK occurred between these dates), we estimate that outsourcing may account for around $40 \%$ of the rise in the wage-bill share of skilled workers and approximately one third of the increase in their employment share in the UK textiles sector. We also show that when assessing the impact of outsourcing the source of imports matters. For the UK, it seems that using aggregate imports to capture outsourcing may be misleading and that disaggregation of imports in order to identify low-wage country sources of supply is necessary. In addition, we find some evidence that low-skill sectors such as textiles are more likely to be influenced by outsourcing than higher-skill sectors and that large currency appreciations may have a disproportionate impact on the economic fortunes of the less-skilled, partly by creating an increased 'threat' of outsourcing. 


\section{INTRODUCTION}

The decline in the relative economic fortunes of unskilled workers in the USA over the past two decades has been extensively documented and analysed. ${ }^{1}$ Studies based upon the traditional neo-classical trade theory have tended to conclude that the increase in imports from low-wage countries has played, at most, a minor role in this development. However, more recent econometric research based on the notion of outsourcing, where firms reduce costs by moving low-skill-intensive production activities to low-wage countries, does find a significant impact of trade on the relative employment and wages of unskilled workers in the USA (see Feenstra and Hanson, 1995 and 1996). Casual but direct evidence also suggests that outsourcing plays a significant role in modern production, for example: Nike only employs 2,500 persons in the USA for marketing and other headquarters services, whereas about 75,000 persons are employed in Asia producing shoes that are sold to Nike; General Electric currently imports all of the microwaves marketed under their brandname from Samsung in Korea (Magaziner and Patinkin, 1989). Outsourcing is also claimed to be an important activity in industries such as footwear (Yoffie and Gomes-Casseres, 1994, case 7), textiles ${ }^{2}$ (Waldinger, 1986; Gereffi, 1993), and electronics (Alic and Harris, 1986). Many of the above examples - such as the General Electric case - also illustrate that outsourcing applies to finished goods as well as intermediate inputs. ${ }^{3}$

\footnotetext{
${ }^{1}$ See, for example, the Summer 1995 and Spring 1997 issues of the Journal of Economic Perspectives.

2 Textile World (1994) provides an idea of the relative level of wages in various low-wage countries in the textiles sector in 1993. For example, medium-income countries such as South Korea and Mexico have hourly compensation levels of around one quarter to one-third of those in the USA, whereas low-income countries such as India, China and Bangladesh have average textile wage rates under 5\% of US levels.

${ }^{3}$ Slaughter (1995) finds that multinational outsourcing contributed very little to the increase in wage inequality in the USA. Differences in the definition of outsourcing partly explain why the results of Feenstra and Hanson differ to those of Slaughter.
} 
In the UK the relative wages and employment of the low-skilled have also fallen dramatically during the 1980s. During that decade the real earnings of the top tenth of male earners in the UK rose at a rate five times faster than that of the earnings of the bottom tenth of male earners. ${ }^{4}$ The unemployment rate of less-skilled males in the UK rose from $6.4 \%$ in the mid1970s to $18.2 \%$ by the mid-1980s, whereas over the same period the unemployment rate of skilled males only rose from $2.0 \%$ to $4.7 \%$ (Nickell, 1996). Although the rise in UK wage inequality has occurred in a number of directions, the most significant widening of relative wages has been between skilled and unskilled workers.

Research into the causes of this deterioration in the economic fortunes of the less-skilled in the UK typically finds that increased trade with the low-wage countries has had very little impact on either the employment or relative wages of low-skilled workers (for example, Machin et al, 1996 and Haskel, 1996a,b). ${ }^{5}$ However, in this paper we follow a different approach to previous UK studies and examine the impact of outsourcing on the relative wages and employment of the less-skilled in the UK. In contrast to previous studies of the USA, which use total imports to proxy outsourcing, we separately identify imports from industrial countries, and those from low-wage countries (as outsourcing to industrial countries is unlikely to directly adversely effect the relative fortunes of unskilled workers). Anderton and Brenton (1998a) show that during the 1980s and early 1990s the low wage countries increased their shares of UK imports across a whole range of sectors, including those typically treated as skilled intensive, such as machinery, but that this growth was uneven across different industries. Hence, we also investigate whether the impact of outsourcing has been the same across both skilled and unskilled-intensive sectors.

\footnotetext{
${ }^{4}$ Source: OECD Employment Outlook July 1993, pp. 157-184, Table 5.3.

${ }^{5}$ The work of Wood (1994) is one obvious major exception.
} 


\section{THEORETICAL FRAMEWORK AND METHOD}

\section{Theoretical framework}

Two main explanations are frequently offered for the apparent shift in demand away from low-skilled workers in industrial countries, which, it is commonly perceived, has contributed to an increase in wage inequality in countries with relatively flexible labour markets (the USA and the UK) and a rise in unemployment for such workers in countries with more rigid labour markets (continental Europe). Firstly, that skill-biased labour-saving technical progress has reduced the relative demand for unskilled workers; second, that increased international trade with nations with an abundant supply of low-skill and low-wage labour has decreased the demand for low-skilled workers in the advanced industrialised countries. Standard trade theory suggests that both of these factors could be responsible for the decline in the fortunes of low-skilled workers in industrial countries and that empirical analysis is required to identify the relative importance of each. ${ }^{6}$

Traditional trade theories primarily explain movements in relative wages across industries, whereas what also needs to be explained is the dramatic fall in the relative wages and employment of unskilled workers within sectors. Indeed, the observed shift away from the use of unskilled labour within industries is in contradiction with trade being the cause of rising inequality in the traditional model. If trade with low-wage countries has reduced the relative wage of unskilled labour then firms within all sectors have an incentive to use relatively more of this now cheaper factor. This has led a number of authors to conclude by deduction that biased technological change must be the principal cause of the shift away from the use of

\footnotetext{
${ }^{6}$ For a review of the standard Hecksher-Ohlin and Stolper-Samuelson issues concerning the links between trade and relative wages see Brenton (1998).
} 
unskilled labour. However, the impact of globalisation appears to be more complicated than is allowed for within the confines of standard factor proportions trade theory. We need to look more carefully at how firms within sectors respond to the more intense competition provided by increased imports from low-wage countries.

One explanation of how trade with low-wage countries may push down the relative wages and employment of unskilled workers within industries is provided by the notion of 'outsourcing'. Outsourcing occurs where firms take advantage of both the low-wage costs of relatively labour abundant countries and modern production techniques - whereby the process of manufacturing a product can be broken-down into a number of discrete activities - by moving the low-skill-intensive parts of production abroad, but continue to carry out the highskill-intensive activities themselves. ${ }^{7}$ Once the low-skill activities have been performed the goods are then imported back from the low-wage countries and either used as intermediate inputs or sold as finished goods. Hence, trade with the low-wage countries via this route will shift employment away from less-skilled towards skilled workers in countries such as the UK, and put downward pressure on the relative wages and employment of low-skilled workers within industries.

Feenstra and Hanson (1995) use industry import shares - imports as a share of consumption in each industry - as a proxy for outsourcing in the USA and the share of non-production workers in the total wage bill to proxy the relative demand for skilled workers in each industry. Using these variables, Feenstra and Hanson estimate that the growth of imports over the period $1979-87$ explains between 15 to 50 per cent of the increase in the share of non- 
production labour in the USA. In this paper, we seek to empirically assess whether outsourcing has been an important phenomenon in the UK. We concentrate on the relative pay and employment of UK non-manual and manual workers in two broad sectors; textiles and non-electrical machinery. In common with most studies on this issue we define nonmanual workers as skilled and manual workers as less-skilled. Textiles are typically seen as requiring the intensive use of unskilled labour, whilst the production of non-electrical machinery is usually treated as using relatively large inputs of skilled labour. Charts 1 and 2 below show the proportions of the total wage bill and total employment accounted for by nonmanual workers in our two sectors for the sample period 1970-1986. The charts clearly show that in both sectors non-manual workers increased their share of the wage bill and employment during the sample period.

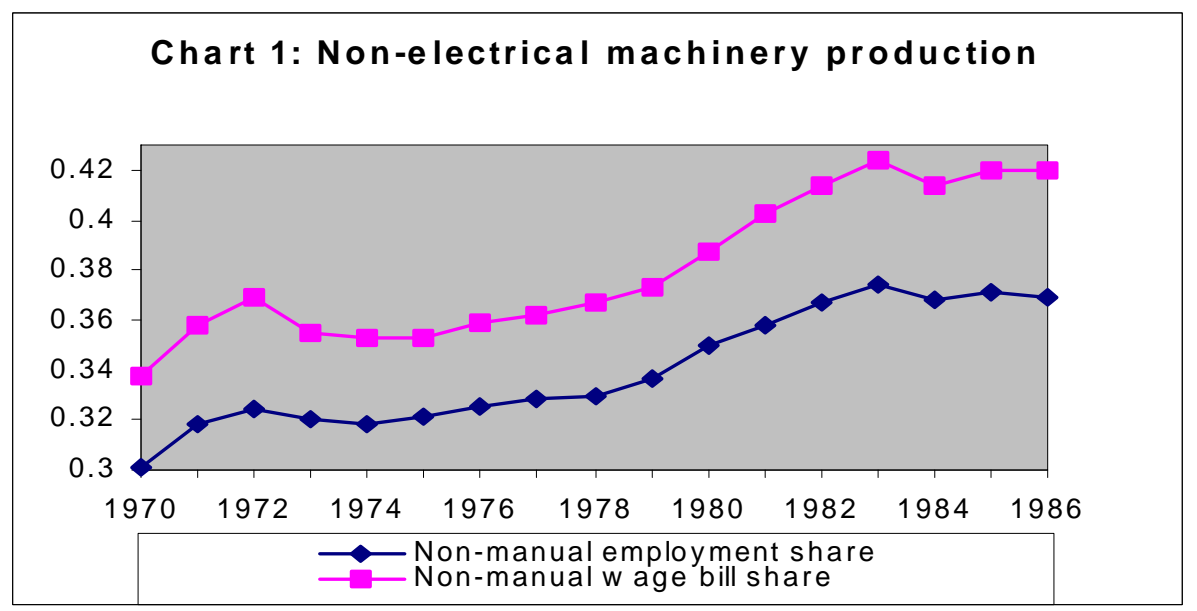

\footnotetext{
7 "Moving the low-skill-intensive parts of production abroad" does not necessarily mean that the firm is involved in outward foreign direct investment, it can also mean that the low-skill parts of production are closed-down and replaced by imports, of intermediate or finished goods, from low-wage countries.
} 


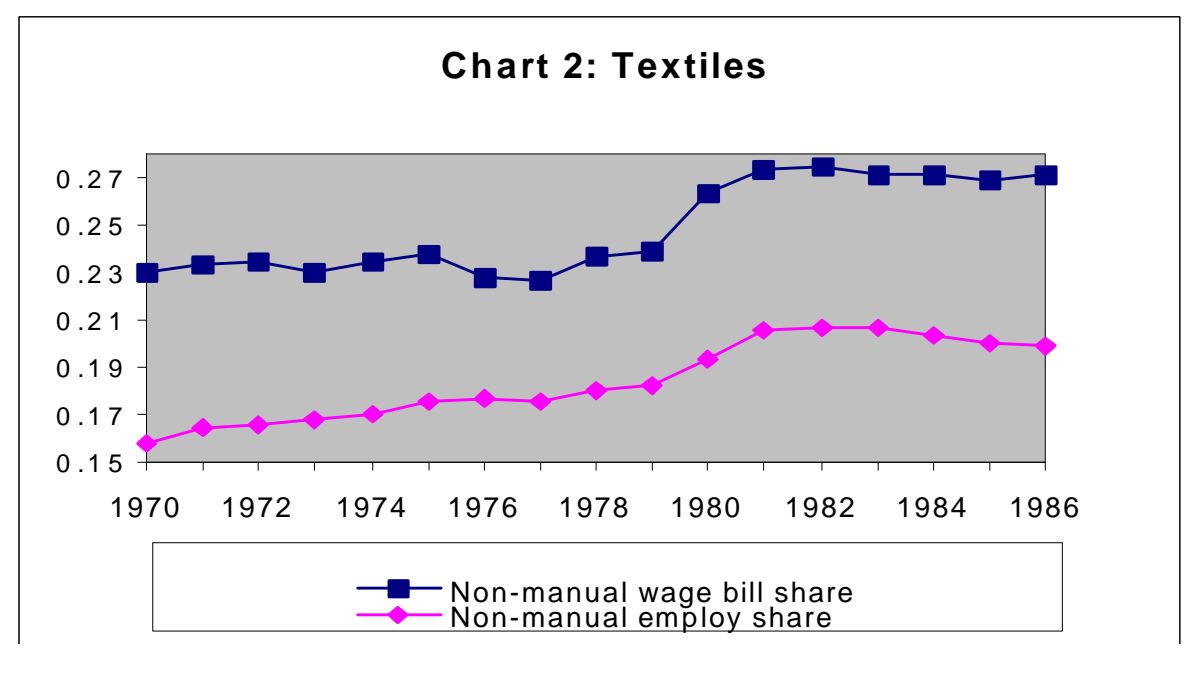

Our approach is to econometrically estimate the impact of outsourcing using a proxy variable similar to Feenstra and Hanson (1996). However, Feenstra and Hanson (1996) proxy outsourcing by the share of imports in total USA consumption from all countries, which implicitly captures the outsourcing of USA production to advanced industrialised countries as well as to the low-wage countries. However, there is no obvious reason why firms would outsource low-skill-intensive activities, which is a key mechanism by which outsourcing may affect the demand for the less-skilled, to advanced industrialised countries which are relatively abundant in skilled labour. Consequently, in this paper we examine whether the source of imports matters. We therefore disaggregate UK imports according to individual supplier countries and construct an import share term for different groups of countries - ie, industrialised and low-wage countries - for each 4-digit industry within the broader categories of textiles and non-electrical machinery. Thus, we explicitly identify imports solely from low-wage countries and use this as a variable for explaining changes in the 
relative wages and employment of the low-skilled in the UK, and thereby more accurately proxy outsourcing to low-wage countries.

We also investigate two other closely related hypotheses. First, given that one might expect low-skill-intensive industries (such as textiles) to be more prone to outsourcing than highskill-intensive sectors, we investigate whether the degree of outsourcing differs across industries. Second, we also consider whether the large appreciation of sterling in the early 1980s had a disproportionate impact on outsourcing due to factors such as switching costs ie, if there are costs involved in moving from domestic sources of supply to a foreign source then a large appreciation of the currency of the importing country may result in a price differential vis-a-vis low-wage country suppliers which is large enough to compensate for the switching costs - and whether this mechanism has any impact on the economic fortunes of the less-skilled by increasing the 'threat' of outsourcing.

\section{Data and econometric analysis}

Following Feenstra and Hanson (1995 and 1996), we seek to assess whether industry import shares have contributed significantly to the determination of the within-sector relative wages of low-skilled workers in the UK. We also estimate equations which explain the relative employment of low-skilled workers. Following the approach of Berman et al (1993, 1994), and assuming capital to be a fixed factor of production, we start from a variable cost function in translog form

$$
\begin{aligned}
& \ln C_{i}=\alpha_{0}+\alpha_{y} \ln Y_{i}+\frac{1}{2} \alpha_{Y Y} \ln \left(Y_{i}\right)^{2}+\beta_{K} \ln K_{i}+\frac{1}{2} \beta_{K K} \ln \left(K_{i}\right)^{2} \\
& +\underset{j}{\sum \gamma_{j}} \ln W_{i j}+\frac{1}{2} \sum_{j k} \sum_{j k} \ln W_{i j} \ln W_{i k}+\sum_{j} \delta \delta_{Y} \ln Y_{i} \ln W_{i j}+\sum_{\mathrm{j}} \delta_{\mathrm{KJ}} \ln \mathrm{K}_{\mathrm{i}} \ln \mathrm{W}_{\mathrm{ij}}+\rho \ln \mathrm{Y}_{\mathrm{i}} \ln \mathrm{K}_{\mathrm{i}}+ \\
& \lambda_{T} T_{i}+\frac{1}{2} \lambda_{T T} T_{i}+\lambda_{Y T} T_{i} \ln Y_{i}+\lambda_{K T} T_{i} \ln K_{i}+\sum_{\mathrm{j}} \varnothing_{\mathrm{iw}} \mathrm{T}_{\mathrm{i}} \ln \mathrm{W}_{\mathrm{ij}}
\end{aligned}
$$


where $C_{i}$ is variable costs in industry $i$,

$\mathrm{Y}_{\mathrm{i}}$ is output in industry $\mathrm{i}$,

$\mathrm{K}_{\mathrm{i}}$ is the capital stock in industry $i$,

$\mathrm{W}_{\mathrm{ij}}$ is the price of variable factor $\mathrm{j}$ and

$\mathrm{T}$ represents technology in industry $i$.

Cost minimisation generates the following linear equations for the factor shares (S):

$S_{i j}=\alpha_{j}+\delta_{Y_{j}} \ln Y_{i}+\delta_{K j} \ln K_{i}+\sum_{K} \gamma_{j k} \ln W_{i k}+\varnothing_{i w_{j}} T_{i}$

Finally, differencing (denoted by d) generates

$d S_{i j}=\varnothing_{i w j} d T_{i}+\delta_{Y j} d \ln Y_{i}+\delta_{K j} d \ln K_{i}+\sum_{k} \gamma_{j k} d \ln W_{i k}$

assuming homogeneity of degree one in prices imposes

$\sum_{\mathrm{K}} \gamma_{\mathrm{iK}}=\sum_{\mathrm{j}} \gamma_{\mathrm{iK}}=\sum_{\mathrm{j}} \delta_{\mathrm{iK}}=\sum_{\mathrm{j}} \delta_{\mathrm{Yj}}=0$

which generates with two variable factors, $\mathrm{j}$ and $\mathrm{k}$

$\mathrm{ds}_{\mathrm{ij}}=\varnothing_{\mathrm{ij}} \mathrm{d}_{\mathrm{i}}+\delta_{\mathrm{Kj}} \mathrm{d} \ln \mathrm{K}_{\mathrm{i}}+\delta_{\mathrm{Yj}} \mathrm{d} \ln \mathrm{Y}_{\mathrm{i}}+\gamma \mathrm{d} \ln \left(\frac{\mathrm{W}_{\mathrm{j}}}{\mathrm{W}_{\mathrm{k}}}\right)$

In our empirical application of the above model we have two variable factors of production, low-skilled (manual) workers and higher-skilled (non-manual) workers, and adopt a similar approach to Machin et al (1996) by estimating the following wage bill share equation using disaggregated industry data pooled over both time and eleven 4-digit industries:

$\mathrm{d} S W_{i t}=\alpha \mathrm{d} \ln K_{i t}+\beta \mathrm{d} \ln Y_{i t}+\rho(R \& D / Y)_{i t-1}+\lambda \mathrm{d} \ln M S_{i t}+\gamma D_{i t}+U_{i t}$

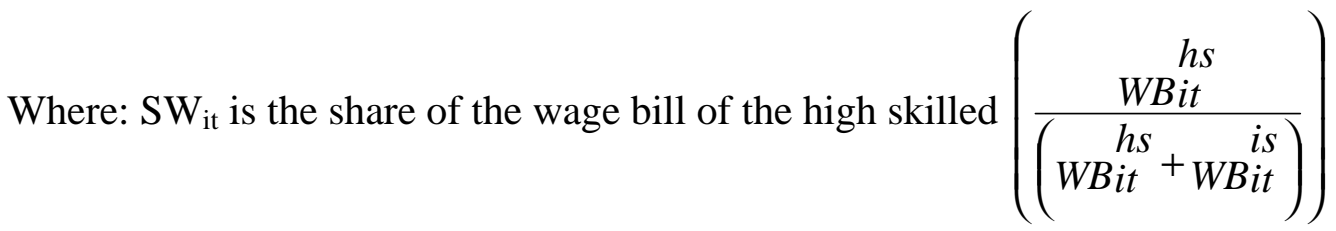
$h s$
$W B i t$ is the wage bill of the higher skilled (ie, non manual).

$l s$
$W B i t$ is the wage bill of the lower skilled (ie, manual). 
$\mathrm{R} \& \mathrm{D}_{\mathrm{it}-1}$ is research and development expenditure which is included as a proxy for technological change,

$\mathrm{MS}_{\mathrm{it}}$ is the share of the value of domestic demand for the output of industry $\mathrm{i}$

accounted for by imports,

$\mathrm{D}_{\mathrm{it}}$ is a set of time dummies included to capture any company preferences for nonmanual or manual workers common across industries for a given year,

$\mathrm{U}$ is an error term.

The MS term is included to capture the impact of outsourcing at the industry level. Following the discussion above, in addition to including the share of total imports we also disaggregate imports by their source and experiment with two other versions of MS:

1. MSI = imports from industrialised countries.

2. MSV = imports from the NICs and very-low wage countries, that is, Singapore, S. Korea, Taiwan, Hong Kong plus the former Comecon countries, China and other Asian developing countries, Latin America and African countries.

Feenstra and Hanson $(1995,1996)$ justify the inclusion of the MS term in the wage bill share equation by arguing that merely including the factors derived from a traditional translog cost function will not capture other factors, such as outsourcing, which may influence a firm's demand for skilled labour. Given that outsourcing to low-wage countries is claimed to push the range of activities performed by domestic industry away from low-skill towards high-skill tasks, the MS term can be interpreted as representing a reduced-form relationship between outsourcing and a firm's unit input requirement for skilled labour. ${ }^{8}$

Note that our wage-bill share equation does not include the relative wage rates for the two types of labour mainly because relative wages are unlikely to be exogenous and there is also the problem of the definitional relationship between the dependent variable (the share of the

\footnotetext{
${ }^{8}$ However, a more rigorous derivation of equation (6) could begin by including either labour in low-wage countries as another factor of production, or outsourced intermediate goods (represented in either price or quantity terms), in the cost function. Such an approach is beyond the scope of this paper, but we hope to carry out a more complete derivation in future work.
} 
wage bill) and the relative wage term. In addition to the wage share equations we also estimate the following employment share equation

$$
\mathrm{d} S E_{i t}=\alpha \mathrm{d} \ln K_{i t}+\beta \mathrm{d} \ln Y_{i t}+\rho(R \& D / Y)_{i t-1}+\lambda \mathrm{d} \ln M S_{i t}+\omega \mathrm{d} \ln R W_{i t}+\gamma D_{i t}+U_{i t}
$$

where $\mathrm{SE}_{\mathrm{it}}$ is the share of high-skilled workers in total employment in sector $\mathrm{i}$

$\mathrm{RW}_{\mathrm{it}}$ is the wage of the high-skilled workers relative to the low-skilled.

Although the derivation of this equation is less satisfactory from a theoretical point of view, it should provide interesting empirical insights in addition to the wage bill equations and allows us to compare our results with those of previous studies, such as Machin et al (1996), who also estimate employment share equations.

\section{Data}

We use disaggregated wage and employment data, taken from the UK Census of Production and converted to the International Standard Industrial Classification (ISIC), for the two broad UK sectors, textiles and non-electrical machinery. Changes in technology are proxied by expenditures on R \& D as a proportion of GDP (source: OECD ANBERD database). The capital stock data are from O’Mahoney et al (1994), whilst imports and domestic production are taken from the bilateral trade dataset derived by Brenton and Winters (1992). The period of analysis is 1970 to 1986 . The trade, production, employment and wage data are all obtained at the 4-digit level of the ISIC and the period of analysis is 1970 to 1986 . In order to provide sufficient observations for estimation we pool the data across eleven ISIC sectors (six in the textiles industry and five in the non-electrical machinery production industry) and apply panel estimation techniques. Given that we lose one observation because we estimate a first difference model, our estimation period 1971-1986 therefore provides us with 176 
observations. Estimates including the R\&D term are based on 143 observations over the sample period 1974-1986 (as the R\&D data only begin in 1973). ${ }^{9}$

\section{EMPIRICAL RESULTS}

We begin by examining the importance of our different measures of import penetration in explaining changes in the share of the wages and employment of the higher-skilled in the UK textiles and non-electrical machinery sectors. We first estimate our basic equations (6) and (7) using total import penetration but we exclude the R\&D term from our specifications (due to apparent multicollinearity with the capital stock term - this is discussed in more detail below). The results, shown in column 1a in Tables 1 and 2 for the wage bill and employment share specifications respectively, suggest that total import penetration has not significantly affected changes in the relative wages and employment of the low-skilled in our limited sample of UK sectors. We then investigate the role of imports from specific groups of countries by experimenting with our import penetration measures for industrial and lowwage countries. We consistently find that only the import penetration term for the low-wage countries is positively signed and statistically significant (a positive sign means that an increase in import penetration from low-wage countries pushes down the relative wage bill and employment shares of the less-skilled). ${ }^{10}$ For example, the results in column $1 \mathrm{c}$ of Tables 1 and 2 show that imports from the low-wage countries (MSV) have a statistically significant influence on the share of the wage income and employment of the less-skilled, whereas the results in column $1 \mathrm{~b}$ show that imports from the industrialised countries (MSI) have no effect on the relative economic fortunes of the less-skilled. Both sets of results are therefore consistent with our a priori expectations regarding the impact of outsourcing.

\footnotetext{
${ }^{9}$ A more comprehensive description of the data are available in Anderton and Brenton (1998b) and the Data Appendix provides details of the eleven 4-digit sectors.
} 
Our results therefore differ from those of Feenstra and Hanson $(1995,1996)$ - who find a significant role for total imports in explaining wage inequality in the US - as we demonstrate that for the UK it is important to disaggregate UK imports according to the country of origin. However, the difference between these two sets of results may be explained by differences in the structure of trade for the two countries. For example, almost one half of total US imports currently come from non-industrial countries, whilst only 24 per cent of UK imports came from these countries. So, even though low-wage countries typically comprise a relatively small share of UK imports, increased trade with these countries appears to have had a significant impact on the relative wage and employment opportunities of the less-skilled.

The wage bill share equations (Table 1) show that a change in output is negatively signed and a change in the capital stock is positively signed, but both variables are not statistically significant. ${ }^{11}$ The signs for these two variables conform with our priors as we expect complementarities between capital and skill and a short-run decline in output tends to hurt the wages and employment of the less-skilled relative to the skilled. ${ }^{12}$ Furthermore, the employment share equation (Table 2) shows that an increase in the relative wages of skilled workers does indeed decrease the relative demand for skilled workers. In general, the

\footnotetext{
${ }^{10}$ This was true for all of the specifications shown in Tables 1 to 4 .

${ }^{11}$ F-tests on our basic specifications show that we can jointly restrict both the intercept and slope parameters to be equal across all of the sectors at the 5 per cent level of significance, hence panel estimation by pooling the data across all 11 sectors is acceptable. For example, the F-tests for equation $(1)$ are $[F(40,132)=1.2857]$ and $[F(50,121)=1.1093)]$ for the wage bill and employment share equations respectively (these are the F-tests for the unrestricted versus the pooled specifications as we test whether $\mathrm{A}, \mathrm{B}=\mathrm{Ai}, \mathrm{Bi}$ where $\mathrm{A}$ represents the intercept and $\mathrm{B}$ the slope parameter).

${ }^{12}$ Kraft (1996) argues that the ratio of skilled to unskilled workers will vary counter-cyclically because skilled workers will be retained by a firm during a recession because they are costly to train. Hence, primarily unskilled workers will be laid-off during a recession.
} 
equations perform fairly well with an R-squared usually exceeding those reported in Machin et al (1996). ${ }^{13}$

Column 2 in tables 1 and 2 shows the results when we include the R\&D technology proxy along with the MSV term, but we exclude the capital stock term as the inclusion of both terms tends to decrease the ' $\mathrm{t}$ '-statistic of both variables (possibly due to multicollinearity). ${ }^{14}$ It can be seen that the $R \& D$ term has a positive sign in both specifications - which is consistent with the idea that skill-biased labour saving technological progress has damaged the relative economic fortunes of the less-skilled - but it is not statistically significant (although the t-statistic is usually above 1). Again, the low-wage country import penetration term is strongly significant and positively signed regardless of whether or not the R\&D term is included.

Our earlier tests showed that it is acceptable to impose a common slope parameter across all of the different sectors, but this is a joint test of all of the slope parameters and it may be the case that some of the parameters differ between the textiles and non-electrical machinery production industries. Therefore, in contrast with previous empirical studies in this area, which usually assume that trade with low-wage countries affects all industries equally, we examine whether there are differences across sectors. In particular, we investigate whether non-electrical machinery production is less prone to outsourcing relative to the textile

\footnotetext{
${ }^{13}$ In general, we experiment with various versions of key variables (ie, lagging variables or using log versions, etc) and the results reported in the tables are for the best performing versions. For example, we experimented with equations (6) and (7) by using a non-logged version of the import penetration term. The non-logged MSV import penetration terms remained strongly significant with parameters (t-statistics) of $0.4368(2.28)$ and 0.4446 (3.18) for the wage bill and employment shares respectively and the parameters and t-statistics of the other variables in the equation remained virtually unchanged (however, in subsequent equations we prefer to use the logged version of the MSV term as this delivers a higher $\mathrm{R}^{2}$ ).

${ }^{14}$ Consequently our procedure throughout this paper is to show the results including the capital stock and R\&D terms separately but not together. This procedure has the added advantage that whenever we exclude the R\&D terms we also benefit from a longer sample period.
} 
industry (which is possible given that textiles is usually viewed as low-skill-intensive and machinery as high-skill-intensive).

The first two columns in Tables 3 and 4 show estimates of equations (6) and (7) (the first including the capital stock, the second with the R\&D term) but with a dummy variable for import penetration from low-wage countries in non-electrical machinery production (that is, $\operatorname{dlnMSV}_{\text {nem,t }}=\operatorname{dlnMSV}_{\text {it }}$ multiplied by a dummy variable with a value of 1 for non-electrical machinery production sectors and 0 otherwise). Both the wage bill and employment share equations show a negative parameter for $\mathrm{dlnMSV}_{\text {nem,t }}$ suggesting that non-electrical machinery production may be less prone to outsourcing relative to textiles. The parameter on $\operatorname{dln}_{\mathrm{n}} \mathrm{V}_{\text {nem, }}$ is roughly half the magnitude of that on the aggregate $\mathrm{dlnMSV}_{\mathrm{it}}$ term (however, it should be noted that $\mathrm{dlnMSV}_{\text {nem,t }}$ is only sometimes statistically significant at the 10 per cent level of significance). ${ }^{15}$

We also investigated the impact of import prices by replacing the import penetration variable (MSV) with disaggregated relative price (RP) terms - ie, the price of UK imports relative to the UK domestic price for the same product broken down into the same three categories as the import penetration terms (total imports, imports from industrial countries and imports from low-wage countries). ${ }^{16}$ None of the relative price terms were statistically significant.

\footnotetext{
${ }^{15}$ If we replace the non-electrical machinery dummy with a textiles dummy we obtain the expected positive sign. ${ }^{16}$ The relative price term can be interpreted as representing price incentives to outsource. We expect such a term to have a negative sign as a decline in the price of imports from low-wage countries relative to UK domestic prices may encourage outsourcing to low-wage countries, thereby decreasing the demand for less-skilled relative to high-skilled workers. The price of imports is, as usual, proxied by the unit value (value per tonne), whilst domestic prices are derived from producer price information.
} 
Thus, whilst we find that the quantity of imports from low-wage countries affects relative wages and employment for the low-skilled in the UK, import prices do not seem to matter. ${ }^{17}$

However, given that Charts 1 and 2 show a distinctly large increase in inequality in the early 1980s, we also investigated whether there was a disproportionate response to the decline in relative import prices resulting from the large appreciation of sterling at this time. ${ }^{18}$ If there are switching costs involved in moving from a domestic source of supply to a foreign source note that the 'domestic supply' includes components and semi-finished products made inhouse - then a large appreciation may result in a substantial price differential between these competing sources sufficient to cover these costs and encourage a disproportionate rise in outsourcing (alternatively, the increased price differential may be sufficient to compensate for product quality differences between low-wage countries and the UK). ${ }^{19}$ We therefore replaced the import penetration variables in our basic wage share and employment equations with terms comprising the relative price multiplied by annual dummies from 1978 onwards. Again the relative price effects did not have a statistically significant impact upon wage bill or employment shares. However, a particularly large negative effect, sometimes statistically significant at the 10 per cent level, was found for the year 1980 which represents the peak of the sterling appreciation (again, this was only for the term capturing the relative price of imports from low-wage countries).

\footnotetext{
17 This may be due to changes in product quality factors. For example, in the earlier stages of product development, 'learning by doing' may enable low-wage countries to increase the quality of their products without changing product prices and thereby encourage an increase in UK imports of their manufactures. Hence, the correlation between changes in import prices and changes in imports of low-wage country products might be weak (whereas the import penetration term provides a more accurate measure of how successfully low-wage country products are competing with UK products).

${ }^{18}$ Between the first quarter of 1979 and the first quarter of 1981, the sterling efffective exchange rate rose by around 30 per cent, but, by the end of 1983, virtually all of the appreciation had been reversed (ie, the annual vlaue of the effective exchange rate was almost exactly the same in both 1979 and 1983).

${ }^{19}$ For example, producers will incur costs if they have to change or modify their machinery or production techniques when switching from domestically supplied goods to foreign goods. Furthermore, such a change will
} 
Given that the UK textile industry was particularly badly hit by the appreciation of sterling in the early $1980 \mathrm{~s},{ }^{20}$ we tested for differences in relative price elasticities across sectors by reestimating our equations and incorporating a single 1980 relative price dummy for the textiles industry alone (ie, $\operatorname{dnRPV} 80_{\mathrm{t} x \mathrm{t}}=\mathrm{d} \ln R \mathrm{PV}$, the relative price of imports from low-wage countries, multiplied by a dummy variable with a value of 1 for the textile sectors in 1980 and 0 otherwise). The dlnRPV80 $0_{\mathrm{t} x \mathrm{t}}$ term was statistically significant and indicates that the textile industry may have been disproportionately affected by outsourcing due to the large deterioration in UK relative price competitiveness against low wage countries in the early 1980s. ${ }^{21}$ Of course, this effect should be picked up - at least partly - by an increase in the import penetration term, so we then added the dlnRPV $80_{\mathrm{tx}, \mathrm{t}}$ term to equations 1 and 2 of Tables 3 and 4 to see if the relative price term was still significant even when the import penetration term is included, and the results are shown in columns 3 and $4 .^{22}$ The results show that the dlnRPV80 $0_{\mathrm{tx}, \mathrm{t}}$ and dlnMSV terms are both statistically significant and suggests that the relative price term captures other effects in addition to the increase in import penetration. It may be the case that the relative price term in columns 3 and 4 captures the 'threat' of increased competition from low-wage countries (and the associated 'threat' of increased opportunities for reducing labour costs via outsourcing) arising from the large appreciation of sterling. Therefore, as an alternative to reducing labour costs by outsourcing, this increased 'threat' may have encouraged other firms to implement measures which restrain the wages - and

be difficult to reverse even if the large appreciation is fully reversed as UK producers are now familiar with the quality of goods not previously imported.

${ }^{20}$ Anderton (1997) shows that approximately one quarter of a million jobs were lost between 1979-1984 in the UK textiles sector.

${ }^{21}$ A similar term for the non-electrical machinery sectors was not statistically significant.

${ }^{22}$ It is worth noting that the capital stock and R\&D terms both become statistically significant at the $10 \%$ level of significance in the employment share equation when these sector-specific dummies are included. Thus, equation (4) in Table 4 suggests that investment in R\&D, which proxies technological change, may also explain some of the decline in the relative employment opportunities of low-skilled workers in these sectors. 
perhaps terminate the employment - of less-skilled workers in order to remain competitive against low-wage countries. At the same time, the 'threat' of outsourcing may have made it considerably easier for firms to obtain the agreement of their workforce for the implementation of such measures.

\section{COMPARISONS WITH PREVIOUS WORK}

Feenstra and Hanson (1995 and 1996) conclude that outsourcing may explain between 15 to 50 per cent of the increase in the wage bill share of skilled workers in the USA. For the period 1970-83 (Charts 1 and 2 show that most of the change in the relative wages and employment of the less-skilled in the UK occurred between these dates), we estimate that outsourcing may account for around $40 \%$ of the rise in the wage-bill share of skilled workers and approximately one third of the increase in their employment share in the UK textiles sector. ${ }^{23}$

In contrast to our results, neither Haskel (1996a,b) nor Machin et al (1996) find a significant impact of trade on the relative wages and employment of the less-skilled in the UK. However, neither study uses trade data which separately identifies imports from low-wage countries, nor do they test for differences across sectors. ${ }^{24}$ Haskel (1996a,b) and Machin et al (1996) conclude that technology and changes in labour market institutions explain the bulk of the declines in the economic fortunes of the less-skilled in the UK (both studies find that declines in union density are associated with a decline in the relative employment and wages of less-

\footnotetext{
${ }^{23}$ For simplicity these calculations are based upon the change in the non-logged MSV term between 1970 and 1983, and then multiplying this value by the appropriate parameter (ie, 0.4368 and 0.4446 for the wage-bill and employment shares respectively) and expressing this as a proportion of the change in the wage bill and employment shares of non-production workers in the Textiles sector during the same period.

${ }^{24}$ However, it should be noted that the Haskel and Machin et al studies may give different results for other reasons (ie, both studies use different sample periods; Haskel uses the New Earnings Survey Panel Dataset and Machin et al uses United Nations data to construct relative employment and earnings series).
} 
skilled workers). However, one might argue that the bulk of the decline in the relative employment of the less-skilled occurred too early in the 1980s to be caused by a decline in union power proxied by the fall in union density. Indeed it seems more plausible that the decline in trade union density was the outcome of the relative employment decline of production workers, which begs the question as to what caused the job losses of the lessskilled in the UK in the early 1980s. This paper suggests that 'outsourcing' to low-wage countries provides a significant part of the answer.

\section{SUMMARY}

Although it should be noted that this study only looks at a small part of UK manufacturing, we do find some evidence that outsourcing may have damaged the economic fortunes of the less-skilled in the UK. We have shown that when assessing the impact of outsourcing the source of imports matters. For the UK, it seems that using aggregate imports to capture outsourcing may be misleading and that disaggregation of imports in order to identify lowwage country sources of supply is necessary. In addition, we find some evidence that lowskill sectors such as textiles are more likely to be influenced by outsourcing than higher-skill sectors and that large currency appreciations may have a disproportionate impact on the economic fortunes of the less-skilled, partly by creating an increased 'threat' of outsourcing. 
TABLE 1: WAGEBILL SHARE EQUATIONS (dSW ${ }_{\text {it }}$ )

\begin{tabular}{|c|c|c|c|c|}
\hline EQUATION & (1a) & (1b) & (1c) & (2) \\
\hline $\mathrm{C}$ & $\begin{array}{c}0.32^{1} \\
(0.75)\end{array}$ & $\begin{array}{c}0.31^{1} \\
(0.72)\end{array}$ & $\begin{array}{c}0.32^{1} \\
(0.75)\end{array}$ & $\begin{array}{l}0.12^{2} \\
(0.03)\end{array}$ \\
\hline$d \ln Y_{i t}$ & $\begin{array}{l}-0.34^{1} \\
(0.42)\end{array}$ & $\begin{array}{l}-0.59^{1} \\
(0.73)\end{array}$ & $\begin{array}{l}-0.63^{1} \\
(1.03)\end{array}$ & $\begin{array}{l}-0.81^{1} \\
(1.28)\end{array}$ \\
\hline$d \ln K_{i t}$ & $\begin{array}{l}0.097 \\
(1.09)\end{array}$ & $\begin{array}{l}0.093 \\
(1.03)\end{array}$ & $\begin{array}{c}0.089 \\
(1.04)\end{array}$ & - \\
\hline$(R \& D / Y)_{i t-1}$ & - & - & - & $\begin{array}{l}0.143 \\
(1.06)\end{array}$ \\
\hline dlnMS $S_{\text {it }}$ & $\begin{array}{c}0.013 \\
(1.21)\end{array}$ & - & - & \\
\hline $\mathrm{d} \ln \mathrm{MSI}_{\mathrm{it}}$ & - & $\begin{array}{c}0.75^{1} \\
(0.71)\end{array}$ & - & - \\
\hline dlnMSV $\mathrm{it}_{\mathrm{it}}$ & - & - & $\begin{array}{l}0.014 \\
(3.23)\end{array}$ & $\begin{array}{l}0.015 \\
(3.25)\end{array}$ \\
\hline $\mathrm{N}$ & 176 & 176 & 176 & 143 \\
\hline $\mathrm{R}^{2}$ & 0.2999 & 0.2957 & 0.3374 & 0.3309 \\
\hline SEE & 0.01332 & .01336 & .01296 & .01325 \\
\hline
\end{tabular}

TABLE 2: EMPLOYMENT SHARE EQUATIONS (dSE it)

\begin{tabular}{|c|c|c|c|c|}
\hline EQUATION & (1a) & (1b) & (1c) & (2) \\
\hline $\mathrm{C}$ & $\begin{array}{c}0.41^{1} \\
(1.28)\end{array}$ & $\begin{array}{c}0.39^{1} \\
(1.23)\end{array}$ & $\begin{array}{c}0.41^{1} \\
(1.36)\end{array}$ & $\begin{array}{c}0.14^{2} \\
(0.41)\end{array}$ \\
\hline$d \ln Y_{i t}$ & $\begin{array}{l}0.012^{1} \\
(0.21)\end{array}$ & $\begin{array}{l}-0.17^{1} \\
(0.29)\end{array}$ & $\begin{array}{c}0.28^{2} \\
(0.06)\end{array}$ & $\begin{array}{l}-0.11^{1} \\
(0.22)\end{array}$ \\
\hline$d \ln K_{i t}$ & $\begin{array}{l}0.071 \\
(1.07)\end{array}$ & $\begin{array}{l}0.064 \\
(0.95)\end{array}$ & $\begin{array}{l}0.067 \\
(1.07)\end{array}$ & - \\
\hline$d \ln R W_{i t}$ & $\begin{array}{l}-0.041 \\
(2.25)\end{array}$ & $\begin{array}{l}-0.041 \\
(2.22)\end{array}$ & $\begin{array}{l}-0.037 \\
(2.13)\end{array}$ & $\begin{array}{r}-0.049 \\
(2.38)\end{array}$ \\
\hline$(R \& D / Y)_{i t-1}$ & & - & - & $\begin{array}{c}0.119 \\
(1.19)\end{array}$ \\
\hline dlnMS $S_{\text {it }}$ & $\begin{array}{c}0.88^{1} \\
(1.11)\end{array}$ & - & - & \\
\hline $\mathrm{d} \ln \mathrm{MSI}_{\mathrm{it}}$ & - & $\begin{array}{l}-0.27^{1} \\
(0.34)\end{array}$ & - & - \\
\hline dlnMSV $V_{\text {it }}$ & - & - & $\begin{array}{l}0.013 \\
(4.06)\end{array}$ & $\begin{array}{l}0.013 \\
(3.83)\end{array}$ \\
\hline $\mathrm{N}$ & 176 & 176 & 176 & 143 \\
\hline $\mathrm{R}^{2}$ & 0.2592 & 0.2539 & 0.3247 & 0.3099 \\
\hline SEE & 0.00987 & .00993 & .00942 & .00991 \\
\hline
\end{tabular}

NOTES TO TABLES 1 and 2: 1, 2,3 Parameters are E-02, E-03, E-04. (i) OLS estimation (full set of time dummies included); (ii) 't' statistics are in parentheses; (iii) $C=$ intercept; $\mathrm{SW}_{\mathrm{it}}=$ non-manual wage bill in sector $\mathrm{i} ; \mathrm{Y}_{\mathrm{it}}=$ real output in sector $\mathrm{i} ; \mathrm{K}_{\mathrm{it}}=$ capital stock for sector $\mathrm{i} ;(R \& D / Y)_{i t-1}=\mathrm{R} \& \mathrm{D}$ expenditure divided by nominal GDP for sector $\mathrm{i} ; \mathrm{MS}_{\mathrm{it}}=$ value of total UK imports divided by UK domestic sales plus total imports for sector $\mathrm{i}$; MSI $\mathrm{it}_{\mathrm{it}}=$ as for MS but only imports from advanced industrialised countries; $\mathrm{MSV}_{\mathrm{it}}=\mathrm{as}$ for MS but only for imports from the NICS and the very low-wage countries; $\mathrm{SE}_{\mathrm{it}}=$ employment of non-manual relative to manual workers in sector $\mathrm{i}$; $\mathrm{RW}_{\mathrm{it}}=$ wage rate of non-manual workers relative to manual workers in sector $\mathrm{i}$. 
TABLE 3: WAGEBILL SHARE EQUATIONS $\left(\mathrm{dSW}_{\text {it }}\right)$

\begin{tabular}{|c|c|c|c|c|}
\hline EQUATION & $(1)$ & (2) & (3) & $(4)$ \\
\hline $\mathrm{C}$ & $\begin{array}{c}0.34^{2} \\
(0.81)\end{array}$ & $\begin{array}{l}-0.81^{3} \\
(0.18)\end{array}$ & $\begin{array}{c}0.38^{1} \\
(0.94)\end{array}$ & $\begin{array}{l}-0.13^{1} \\
(0.29)\end{array}$ \\
\hline$d \ln Y_{i t}$ & $\begin{array}{l}-0.66^{1} \\
(1.09)\end{array}$ & $\begin{array}{l}-0.86^{1} \\
(1.38)\end{array}$ & $\begin{array}{l}-0.61^{1} \\
(1.01)\end{array}$ & $\begin{array}{l}-0.82^{1} \\
(1.33)\end{array}$ \\
\hline $\mathrm{d} \ln \mathrm{K}_{\mathrm{it}}$ & $\begin{array}{l}0.106 \\
(1.22)\end{array}$ & - & $\begin{array}{c}0.138 \\
(1.60)\end{array}$ & - \\
\hline$(R \& D / Y)_{i t-1}$ & - & $\begin{array}{l}0.191 \\
(1.38)\end{array}$ & - & $\begin{array}{c}0.219 \\
(1.62)\end{array}$ \\
\hline dlnMSV $_{\text {it }}$ & $\begin{array}{l}0.018 \\
(3.23)\end{array}$ & $\begin{array}{l}0.020 \\
(3.48)\end{array}$ & $\begin{array}{l}0.016 \\
(3.11)\end{array}$ & $\begin{array}{l}0.019 \\
(3.34)\end{array}$ \\
\hline $\mathrm{d} \ln R P V 80_{\mathrm{tx}, \mathrm{t}}$ & - & - & $\begin{array}{l}-0.065 \\
(2.71)\end{array}$ & $\begin{array}{l}-0.061 \\
(2.55)\end{array}$ \\
\hline$d \operatorname{lnMSV} V_{\text {nem,t }}$ & $\begin{array}{l}-0.91^{1} \\
(1.15)\end{array}$ & $\begin{array}{l}-0.013 \\
(1.45)\end{array}$ & $\begin{array}{l}-0.79^{1} \\
(1.03)\end{array}$ & $\begin{array}{l}-0.012 \\
(1.33)\end{array}$ \\
\hline $\mathrm{N}$ & 176 & 143 & 176 & 143 \\
\hline $\mathrm{R}^{2}$ & 0.3429 & 0.3419 & 0.3728 & 0.3744 \\
\hline SEE & .01295 & .01319 & .01269 & .01291 \\
\hline
\end{tabular}

TABLE 4: EMPLOYMENT SHARE EQUATIONS (dSE $\left.{ }_{i \mathrm{t}}\right)$

\begin{tabular}{|c|c|c|c|c|}
\hline EQUATION & (1) & (2) & (3) & (4) \\
\hline $\mathrm{C}$ & $\begin{array}{l}-0.44^{1} \\
(1.46)\end{array}$ & $\begin{array}{l}-0.81^{2} \\
(0.08)\end{array}$ & $\begin{array}{c}0.49^{1} \\
(1.65)\end{array}$ & $\begin{array}{c}0.48^{2} \\
(0.15)\end{array}$ \\
\hline$d \ln Y_{i t}$ & $\begin{array}{l}-0.32^{3} \\
(0.01)\end{array}$ & $\begin{array}{l}-0.16^{1} \\
(0.33)\end{array}$ & $\begin{array}{c}0.56^{3} \\
\left(0.13^{1}\right)\end{array}$ & $\begin{array}{l}-0.99^{2} \\
(0.22)\end{array}$ \\
\hline $\mathrm{d} \ln \mathrm{K}_{\mathrm{it}}$ & $\begin{array}{l}0.084 \\
(1.33)\end{array}$ & - & $\begin{array}{c}0.111 \\
(1.79)\end{array}$ & - \\
\hline$d \ln R W_{\text {it }}$ & $\begin{array}{l}-0.035 \\
(2.01)\end{array}$ & $\begin{array}{r}-0.048 \\
(2.37)\end{array}$ & $\begin{array}{l}-0.031 \\
(1.87)\end{array}$ & $\begin{array}{l}-0.043 \\
(2.19)\end{array}$ \\
\hline$(R \& D / Y)_{i t-1}$ & - & $\begin{array}{l}0.159 \\
(1.54)\end{array}$ & - & $\begin{array}{l}0.183 \\
(1.82)\end{array}$ \\
\hline $\mathrm{dlnMSV}_{\mathrm{it}}$ & $\begin{array}{l}0.017 \\
(4.24)\end{array}$ & $\begin{array}{l}0.018 \\
(4.04)\end{array}$ & $\begin{array}{l}0.016 \\
(4.16)\end{array}$ & $\begin{array}{l}0.017 \\
(3.93)\end{array}$ \\
\hline $\mathrm{d} \ln R P V 80_{\mathrm{tx}, \mathrm{t}}$ & - & - & $\begin{array}{r}-0.051 \\
(3.21)\end{array}$ & $\begin{array}{l}-0.052 \\
(2.92)\end{array}$ \\
\hline dlnMSV $\mathrm{nem}, \mathrm{t}$ & $\begin{array}{l}-0.97^{1} \\
(1.70)\end{array}$ & $\begin{array}{r}-0.011 \\
(1.61)\end{array}$ & $\begin{array}{l}-0.89^{1} \\
(1.59)\end{array}$ & $\begin{array}{l}-0.97^{1} \\
(1.49)\end{array}$ \\
\hline $\mathrm{N}$ & 176 & 143 & 176 & 143 \\
\hline $\mathrm{R}^{2}$ & 0.3370 & 0.3241 & 0.3787 & 0.3676 \\
\hline SEE & .00936 & .00985 & .00909 & .00957 \\
\hline
\end{tabular}

NOTES TO TABLES 3 and 4: dlnMSV $V_{\text {nem,t }}=d \ln M S V_{\text {it }}$ multiplied by a dummy variable with a value of 1 for non-electrical machinery sectors and 0 otherwise; dlnRPV80 $0_{t x, t}=$ dlnRPV $_{i, t}$ multiplied by a dummy variable with a value of 1 for textile sectors in 1980 and 0 otherwise. 


\section{DATA APPENDIX: 4-DIGIT SECTORS}

We pool the data across eleven ISIC sectors (six in the textiles industry and five in the nonelectical machinery production industry) over an annual sample period from 1970 to 1986. Given that we lose one observation because we estimate a first difference model, our estimation period 1971-1986 therefore provides us with 176 observations (ie, 16*11). Estimates including the R\&D term are based on 143 observations over the sample period 1974-1986 (as the R\&D data only begin in 1973). The 4-digit ISIC sectors used in the estimation are as follows:

ISIC3211 Spinning, weaving and finishing textiles.

ISIC3212 Manufacture of made-up textile goods, except wearing apparel.

ISIC3213 Knitting mills.

ISIC3214 Manufacture of carpet and rugs.

ISIC3215 Cordage, rope and twine industries.

ISIC3219 Manufacture of textiles not elsewhere classified.

ISIC3821 Manufacture of engines and turbines.

ISIC3822 Manufacture of agricultural machinery and equipment.

ISIC3823 Manufacture of metal and woodworking machinery.

ISIC3824 Manufacture of special industrial machinery and equipment except metal and wood working machinery.

ISIC3829 Machinery and equipment except electrical not elsewhere classified.

UK data from the Census of Production are first classified to a common UK SIC as the data are defined in terms of the 1968 UK SIC (ie, Minimum List Headings: MLH) for the first part of the sample period but defined in terms of the 1980 UK SIC (Activity Headings: AH) in the latter part of the sample period. Therefore, the first task is to compile consistent industry series for the whole sample period by linking the MLH and AH series. This was achieved by following the CSO's Standard Industrial Classification Revised 1980: Reconciliation with Standard Industrial Classification 1968 (CSO, 1980) which gives the correspondence between the AH and MLH series. In cases where only a proportion of the MLH should be allocated to the appropriate AH we calculate the relevant proportion by using the 1979 Census of Production data which was published on the basis of both SIC 1968 and SIC 1980 (hence we have an overlapping observation for the SIC 1968 and 1980 classifications). The second step was to 'map' the consistent UK SIC series to the above ISIC classifications (using a similar methodology to that in Anderton, 1996b). 


\section{References}

Alic, J.A. and Harris, M.C. (1991), 'Appendix: The NBER immigration, trade and labor markets data files', in Borjas, G. and Freeman, R., Editors: Immigration, Trade and the Labour Market. Chicago: University of Chicago Press and NBER, pp. 407-420.

Anderton, R. (1997), 'UK trade performance and the role of product quality, innovation and hysteresis: some preliminary results', National Institute discussion paper no. 102.

Anderton, R. and Brenton, P. (1998a) 'Trade With the NICs and Wage Inequality: Evidence from the UK and Germany' in Brenton, P and Pelkmans, J (eds) Global Trade and European Workers, Macmillan, London

Anderton, R and Brenton, P. (1998b) 'Did outsourcing to low-wage countries hurt less-skilled workers in the UK?', in Brenton, P and Pelkmans, J (eds) Global Trade and European Workers, Macmillan, London

Berman, E., Bound, J. and Griliches, Z. (1993), 'Changes in the demand for skilled labor within US manufacturing industries: evidence from the Annual Survey of Manufactures', National Bureau of Economic Research Working Paper No. 4255.

Berman, E., Bound, J. and Griliches, Z. (1994), 'Changes in the demand for skilled labor within US manufacturing: evidence from the Annual Survey of Manufactures', Quarterly Journal of Economics, Vol. CIX, Issue no. 2, May.

Brenton, P (1998) 'Rising Trade and Falling Wages: A Review of the Theory and the Empirics', in Brenton, $\mathrm{P}$ and Pelkmans, J (eds) Global Trade and European Workers, Macmillan, London

Brenton, P. and Winters, L.A. (1992), 'Estimates of bilateral trade elasticities and their implications for the modelling of 1992', Centre for Economic Policy Research, Discussion Paper No. 717.

Feenstra, R.C. and Hanson, G.H. (1995), 'Foreign investment, outsourcing and relative wages', National Bureau of Economic Research Working Paper No. 5121.

Feenstra, R.C. and Hanson, G.H. (1996), 'Globalization, outsourcing and wage inequality', American Economic Review, Papers and Proceedings, Vol. 86, No. 2, May, pp. 240-245.

Gereffi, G. (1993), 'The role of big buyers in global commodity chains: How US retail networks affect overseas production patterns', in G. Gereffi and M. Korzeniewicz, editors: Commodity Chains and Global Capitalism. Westport CT: Praeger, pp.95-122.

Haskel, J. (1996a), 'The decline in unskilled employment in UK manufacturing' Centre for Economic Policy Research, Discussion Paper No. 1356.

Haskel, J. (1996b), 'Small firms, contracting-out, computers and wage inequality: evidence from UK manufacturing', Centre for Economic Policy Research, Discussion Paper No. 1490. Kraft, K. (1996), 'Wage differentials between skilled and unskilled workers', Weltwirtscaftliches Archiv.

Machin, S., Ryan, A. and van Reenen, J. (1996), 'Technology and changes in skill structure: evidence from a panel an international panel industries', Centre for Economic Policy Research No. 1434.

Magaziner, K. and Patinkin, M. (1989), 'Fast heat: How Korea won the microwave war', Harvard Business Review, January-February, 83-92.

Nickell, S. (1996), 'Unemployment and wages in Europe and North America', The Labour Market Consequences of Technical and Structural Change Discussion Paper Series No.6 (sponsored by the Leverhulme Trust).

O’Mahony, M., Wagner, K. and Paulsen, M. (1994), 'Changing fortunes: an industry study of British and German productivity growth over three decades', National Institute Report Series number 7 . 
Slaughter, M. (1995), 'Multinational corporations, outsourcing, and American wage divergence', National Bureau of Economic Research Working Paper No. 5253.

Waldinger, R.D. (1986), Through the Eye of the Needle, New York: New York University Press.

Wood, A. (1994), North-South Trade, Employment and Inequality: Changing Fortunes in a Skill-Driven World, Oxford University Press, Oxford.

Yoffie, D.B. and Gomes-Casseres, B. (1994), International trade and Competition, New York: Mcgraw-Hill. 